\title{
MANAJEMEN REKRUTMEN PESERTA DIDIK DALAM MENINGKATKAN MUTU LULUSAN
}

\author{
Widya Astuti Permana \\ Universitas Islam Negeri Sunan Gunung Djati Bandung \\ Email: astutipermanawidya@gmail.com
}

\begin{abstract}
ABSTRAK
Sekolah Menengah Pertama Darul Falah Cihampelas Kabupaten Bandung Barat dalam proses rekrutmen peserta didik baru menggunakan sistem seleksi secara tes, bahwa calon peserta didik yang mendaftar diwajibkan menyelesaikan tugas berupa soal-soal tes secara lisan maupun tertulis. Jika peserta didik tersebut dapat menyelesaikan suatu tugas berdasarkan kriteria tertentu yang telah ditentukan sekolah, maka peserta didik tersebut dapat diterima, begitupun sebaliknya. Tujuan penelitian untuk mengetahui manajemen rekrutmen peserta didik dalam meningkatkan mutu lulusan di SMP Darul Falah Cihampelas Kabupaten Bandung Barat. Metode penelitian yang digunakan adalah metode deskriptif dengan menggunakan pendekatan kualitatif. Teknik yang digunakan dalam pengumpulan data yaitu observasi partisipasi, wawancara, dan studi dokumentasi. Analisis data dilakukan dengan kategorisasi data, penafsiran data. Adapun uji absah data dilakukan dengan perpanjangan keikutsertaan, ketekunan pengamatan, triangulasi, cek teman sejawat, analisis kasus negatif, kecukupan referensi dan uraian rinci. Hasil penelitian ini menunjukan bahwa, kegiatan manajemen rekrutmen peserta didik dalam meningkatkan mutu lulusan di SMP Darul Falah Cihampelas Kabupaten Bandung Barat dilakukan melalui beberapa tahapan yaitu kebijakan rekrutmen peserta didik, sistem rekrutmen peserta didik, kriteria penerimaan peserta didik baru, prosedur penerimaan peserta didik baru dengan membentuk panitia penerimaan peserta didik baru, rapat penerimaan peserta didik baru, pembuatan pengumuman peserta didik baru, pemasangan/pengiriman pengumuman peserta didik baru, pendaftaran peserta didik baru, seleksi peserta didik baru, rapat penentuan peserta didik yang diterima, pengumuman peserta didik yang diterima, pendaftaran ulang peserta didik baru.
\end{abstract}

Kata Kunci: Manajemen, Rekrutmen, Peserta Didik

\section{ABSTRACT}

Darul Falah Secondary School first Cihampelas Bandung Regency West in the recruitment of new participants diidk use selection in the test, that prospective students who register are required to complete the task in the form of test questions orally or in writing. If learners are able to complete a task based on 
certain predetermined criteria of the school, the learners can be accepted, and vice versa. The aim of research to determine the management of the recruitment of learners in improving the quality of graduates in SMP Darul Falah Cihampelas West Bandung regency. The method used is descriptive method with qualitative approach. Techniques used in data collection, namely participatory observation, interviews, and documentation. Data analysis was performed with the categorization of data, interpretation of data. The valid test data is done by the extension of participation, persistence observation, triangulation, check peers, negative case analysis, the adequacy of reference and detailed description. These results indicate that management activities recruitment of learners in improving the quality of graduates in SMP Darul Falah Cihampelas West Bandung District performed through several stages recruitment policy of the learners, the system of recruitment of learners, the criteria for admission of new students, the acceptance procedure of new students by forming a new learner admissions committee, meeting admission of new students, creation of new learners announcement,

Key words: Management, Recruitment, Students

\section{PENDAHULUAN}

Pendidikan merupakan salah satu usaha untuk meningkatkan kualitas hidup manusia melalui pengembangan potensi yang mereka miliki. Pendidikan bukanlah kegiatan yang sederhana, melainkan kegiatan yang dinamis. Mempertimbangkan adanya dinamika penyelenggaraan pendidikan, maka pendidikan memerlukan manajemen yang baik agar tujuan pedidikan tercapai dengan efektif dan efisien (Badrudin, 2013).

Mutu sebuah lembaga pendidikan dapat ditentukan oleh beberapa komponen-komponen pendukung seperti kurikulum, pembiayaan, dan sarana prasarana sebagai penunjang di lembaga pendidikan. Adapun komponen lainnya yaitu komponen sumber daya manusia seperti kepala sekolah, guru, manajerial, dan peserta didik. komponen-komponen tersebut merupakan satu kesatuan yang tidak dapat terpisahkan dalam upaya pencapaian tujuan lembaga pendidikan, artinya bahwa suatu komponen tidak lebih penting dari komponen lainnya, akan tetapi satu komponen memberikan dukungan terhadap komponen yang lainnya sehingga memberikan kontribusi yang maksimal terhadap pencapaian tujuan lembaga pendidikan.

Peserta didik dapat dipahami sebagai anggota masyarakat yang berusaha mengembangkan potensi diri melalui proses pembelajaran, orang yang mengharapkan mendapat pelayanan pendidikan sesuai dengan bakat minat dan kemampuannya agar tumbuh dan berkembang dengan baik serta mempunyai kekuasaan dalam menerima pelajaran (Umam, 2018).

Peserta didik juga merupakan salah satu komponen sekolah yang keberadaannya sangat dibutuhkan, terlebih bahwa pelaksanaan kegiatan pendidikan di sekolah, peserta didik merupakan objek dalam proses transformasi ilmu pengetahuan dan keterampilan-keterampilan. Oleh karena itu keberadaan peserta didik tidak hanya untuk memenuhi kebutuhan saja, akan tetapi juga merupakan bagian dalam menciptakan lembaga pendidikan yang bermutu. 
Sehingga peserta didik dapat tumbuh dan berkembang sesuai dengan potensi yang dimilikinya, mulai potensi fisik, kecerdasan intelektual, sosial, emosional, dan kewajiban peserta didik (Tim Dosen Adpen UPI, 2015).

Kebutuhan peserta didik dalam mengembangkan dirinya sangatlah beragam sehingga perlu adanya pengelolaan layanan peserta didik yaitu dengan diterapkannya manajemen peserta didik di suatu lembaga pendidikan atau sekolah. Manajemen peserta didik merupakan suatu layanan yang memusatkan perhatian pada pengaturan, pengawasan, dan layanan sistem siswa di kelas dan di luar kelas seperti pengenalan, pendaftaran, layanan individu, seperti pengembangan keseluruhan kemampuan, minat, kebutuhan sampai ia matang di sekolah (Imron, 2012). Manajemen peserta didik yang bermutu bagi lembaga pendidik sangat dibutuhkan, sehingga peserta didik dapat tumbuh dan berkembang sesuai dengan potensi fisik, kecerdasan intelektual, sosial, emosional, dan kejiwaan peserta didik (Deniyati, 2017).

Terdapat lima kriteria peserta didik yaitu pertama, peserta didik bukanlah miniatur orang dewasa tetapi memiliki dunianya sendiri, kedua, peserta didik memiliki periodesasi perkembangan dan pertumbuhan, ketiga, peserta didik adalah makhluk Allah yang memiliki perbedaan individu baik disebabkan oleh faktor bawaan maupun faktor lingkungan dimana ia berada, keempat, peserta didik memiliki dua unsur utama jasmani dan rohani, unsur jasmani memiliki daya fisik dan unsur rohani memiliki daya akal, hati nurani, dan nafsu, kelima, peserta didik adalah manusia yang memiliki potensi atau fitrah yang dapat dikembangkan dan berkembang secara dinamis (Junaidi, 2016).

Manajemen peserta didik merupakan usaha pengaturan terhadap peserta didik mulai dari peserta didik tersebut masuk sekolah sampai dengan lulus sekolah, adapun kegiatan dari manajemen peserta didik adalah perencanaan, pembinaan, evaluasi dan mutasi (Jahari dkk., 2019). Dengan demikian, manajemen peserta didik bukan hanya dalam lingkup pencatatan peserta didik saja, melainkan meliputi aspek yang lebih luas yang secara operasional dapat membantu kelancaran upaya pertumbuhan dan perkembangan peserta didik melalui proses pendidikan di sekolah. Dalam lingkup manajemen peserta didik yang termasuk didalamnya rekruitmen peserta didik perlu dikelola dengan baik dan benar supaya didapatkannya input yang berkualitas (Heryati \& Muhsin, 2014, hlm. 77).

Kegiatan rekruitmen peserta didik merupakan salah satu program kegiatan sekolah dan termasuk dalam perencanaan peserta didik dalam lingkup manajemen peserta didik. Rekruitmen peserta didik pada hakikatnya merupakan proses pencarian, menentukan peserta didik yang nantinya akan menjadi peserta didik di lembaga sekolah yang bersangkutan. Langkah-langkah kegiatan tersebut adalah pertama, membentuk panitia penerimaan peserta didik baru yang melibatkan semua unsur guru, pegawai TU (Tata Usaha), dan dewan sekolah/ komite sekolah, kedua, pembuatan dan pemasangan pengumuman penerimaan peserta didik baru yang dilakukan secara terbuka, informasi yang harus ada dalam pengumuman tersebut adalah gambaran singkat lembaga, persyaratan pendaftaran siswa baru (syarat umum dan syarat khusus), cara pendaftaran, waktu dan tempat seleksi dan pengumuman hasil seleksi (Badrudin, 2013).

Penerimaan peserta didik baru sebenarnya adalah salah satu kegiatan pengaturan peserta didik yang sangat penting. Kebijakan operasional 
penerimaan peserta didik juga memuat sistem pendaftaran dan seleksi atau penyaringan yang akan diberlakukan untuk peserta didik. Selain itu kebijakan penerimaan peserta didik juga berisi mengenai waktu pendaftaran, kapan dimulai, dan kapan di akhiri. Selanjutnya kebijakan penerimaan peserta didik harus juga memuat tentang personalia-personalia yang akan terlibat dalam pendaftaran seleksi dan penerimaan peserta didik. Kebijakan penerimaan peserta didik ini dapat dibuat berdasarkan petunjuk-petunjuk yang diberikan oleh Dinas Pendidikan. Petunjuk ini harus dipedomani karena memang dibuat dalam rangka mendapatkan calon peserta didik sebagaimana yang diinginkan atau didiamkan (Ardhi, 2015).

Manajemen peserta didik berbasis sekolah dijelaskan bahwa dalam kegiatan penerimaan peserta didik baru yang pertama dilakukan adalah menentukan kebijakan penerimaan peserta didik, kemudian menentukan sistem penerimaan peserta didik, menentukan kriteria penerimaan peserta didik dan membuat prosedur penerimaan peserta didik baru (Imron, 2012).

Dalam penerimaan siswa baru, sekolah juga dituntut untuk memahami dan menunjang azas-azas dalam pelaksanaan penerimaan siswa baru. Azasazas yang harus diperhatikan oleh sekolah antara lain yang pertama adalah objektif, artinya bahwa penerimaan siswa baru, baik siswa baru maupun pindahan harus memenuhi ketentuan umum yang telah ditetapkan. Kedua harus transparan, artinya penerimaan siswa baru bersifat terbuka dan dapat diketahui oleh masyarakat termasuk orangtua siswa, untuk menghindarkan penyimpangan-penyimpangan yang mungkin terjadi. Ketiga harus akuntabel, artinya penerimaan siswa baru dapat dipertanggungjawabkan kepada masyarakat baik prosedur maupun hasilnya. Keempat yaitu tidak diskriminatif, artinya penerimaan siswa baru dilaksanakan tanpa membedakan suku, agama, ras, dan golongan. Serta yang kelima yaitu harus kompetitif, artinya penerimaan siswa baru dilakukan melalui seleksi berdasarkan nilai-nilai yang diperoleh calon siswa dari setiap tahapan seleksi sesuai dengan pembobotan yang sudah ditetapkan (Nizarman, 2015).

Kebijakan penerimaan peserta didik baru sebenarnya menggunakan dasar-dasar manajemen peserta didik. Peserta didik dapat diterima di suatu lembaga pendidikan seperti sekolah, haruslah memenuhi persyaratanpersyaratan sebagaimana yang telah ditentukan. Sungguhpun setiap orang mempunyai hak yang sama untuk mendapatkan layanan pendidikan, tidak secara otomatis mereka dapat di terima di suatu lembaga pendidikan seperti sekolah, sebab untuk dapat diterima haruslah terlebih dahulu memenuhi kewajiban-kewajiban yang telah ditentukan.

Kebijakan operasional penerimaan peserta didik baru, memuat aturan mengenai jumlah peserta didik yang dapat diterima di suatu sekolah. Penentuan mengenai jumlah peserta didik, tentu juga didasarkan atas kenyataan-kenyataan yang ada di sekolah (faktor kondisional sekolah). Faktor kondisional tersebut meliputi daya tampung kelas baru, kriteria mengenai siswa yang dapat di terima, anggaran yang tersedia, jumlah peserta didik yang tinggal di kelas satu, dan sebagainya. Kebijaksanaan penerimaan peserta didik ini dibuat berdasarkan petunjuk-petunjuk yang diberikan oleh Dinas Pendidikan Kabupaten/ Kota. Petunjuk demikian harus dipedomani karena ia memang dibuat dalam rangka mendapatkan calon peserta didik sebagaimana yang diinginkan atau diidealkan. 
Ada dua macam penerimaan peserta didik baru. Pertama, dengan menggunakan sistem promosi, sedangkan yang kedua dengan menggunakan sistem seleksi. Yang dimaksud dengan promosi adalah penerimaan peserta didik yang sebelumnya tanpa menggunkan seleksi. Cara promosi demikian, secara umum berlaku pada sekolah-sekolah yang pendaftarannya kurang dari jatah atau daya tampung yang ditentukan. Kedua, adalah dengan cara seleksi. Cara seleksi ini dapat digolongkan menjadi tiga macam, yaitu seleksi berdasarkan daftar nilai Ujian Akhir Nasional (UAN), seleksi berdasarkan penelusuran minat dan bakat (PMDK), dan seleksi berdasarkan hasil tes masuk (Prihatin, 2011).

Kriteria penerimaan peserta didik baru adalah patokan-patokan yang menentukan bisa atau tidaknya seseorang untuk diterima sebagai peserta didik. Ada tiga macam kriteria penerimaan peserta didik baru yaitu pertama kriteria acuan patokan (standard criterian referenced). Suatu penerimaan peserta didik yang didasarkan atas patokan-patokan yang telah ditentukan sebelumnya. Dalam hal ini, sekolah terlebih dahulu membuat patokan bagi calon peserta didik dengan kemampuan minimal setingkat dengan sekolah yang menerima peserta didik. Jadi, jika semua peserta didik yang mengikuti seleksi memenuhi patokan minimal yang sudah ditentukan sekolah maka mereka harus diterima semua. Sebaliknya, jika calon peserta didik yang mendaftar kurang memenuhi patokan minimal yang telah ditentukan, peserta didik akan ditolak atau tidak diterima. Kedua yaitu kriteria acuan norma (norm criterain referenced). Penerimaan peserta didik yang didasarkan atas keseluruhan prestasi calon peserta didik yang mengikuti seleksi. Dalam hal ini sekolah menetapkan kriteria penerimaan berdasarkan prestasi keseluruhan peserta didik. keseluruhan prestasi peserta didik dijumlah, kemudian dicari rata-ratanya. Ketiga yaitu kriteria yang didasarkan atas daya tampung sekolah. Sekolah terlebih dahulu menentukan berapa jumlah daya tampungnya, atau berapa calon peserta didik baru yang akan diterima. Setelah sekolah menentukan, kemudian meranking prestasi siswa mulai dari yang berprestasi paling tinggi sampai dengan prestasi paling rendah, penentuan peserta didik yang diterima dilakukan dengan cara mengurut dari atas ke bawah, sampai daya tampung tersebut terpenuhi.

Ada beberapa prosedur penerimaan peserta didik baru yang dapat dilakukan adalah (1) pembentukan panitia penerimaan peserta didik baru; (2) rapat penentuan peserta didik baru; (3) pembuatan, pemasangan atau pengiriman pengumuman; (4) pendaftaran peserta didik baru; (5) seleksi; (6) penentuan peserta didik yang diterima; (7) pengumuman peserta didik yang diterima; dan (8) registrasi peserta didik yang diterima (Imron, 2012).

Kegiatan penerimaan peserta didik baru diharapkan tidak hanya sematamata untuk menerima dan menolak peserta didik saja, akan tetapi jauh kedepan untuk mengetahui tingkat kecerdasan peserta didik. Dengan tingkat kecerdasan tersebut dapat membantu dalam menentukan proses pembinaan dan bahkan untuk dapat menentukan target dan arah pendidikan di masa depan. Seleksi penerimaan peserta didik baru harus dipahami sebagai sebuah proses mendapatkan peserta didik yang unggul. Sehingga dalam proses kegiatan ini lembaga pendidikan harus merencanakan secara matang. Agar tujuan dilaksanakannya seleksi yaitu peningkatan mutu lulusan dapat tercapai dan dilakukan secara efektif dan efisien. 
Manajemen peningkatan mutu lulusan merupakan sebuah proses yang melibatkan semua bagian dalam lembaga pendidikan. Semua bagian tersebut saling berhubungan dan tidak dapat dipisahkan, bagian tersebut diantaranya adalah siswa, tenaga pendidik/guru, kepala sekolah, serta stakeholder atau masyarakat sebagai pengguna lulusan. Kesemua bagian tersebut harus sinergi untuk menghasilkan kinerja sekolah berupa prestasi siswa yang memuaskan (Ubaidillah, 2017).

Mutu lulusan tidak terjadi begitu saja, ia harus direncanakan secara sistematis dengan menggunakan proses manajemen peningkatan mutu lulusan yang diharapkan. Manajemen peningkatan mutu ini meliputi penyusunan perencanaan peningkatan mutu, pengorganisasian, pelaksanaan manajemen peningkatan mutu lulusan. Hal ini didasarkan dengan melihat secara obyektif, tajam dan realistis kondisi-kondisi eksternal dan internal, sehingga dapat mengantisipasi perubahan lingkungan yang akan terjadi. Manajemen peningkatan mutu lulusan yang direncanakan agar output yang dihasilkan mampu bersaing untuk melanjutkan jenjang pendidikan di tingkat yang lebih tinggi (Tien, 2015).

Berdasarkan hasil studi pendahuluan yang telah dilakukan, diperoleh gambaran bahwa dalam kegiatan rekruitmen peserta didik baru di SMP Darul Falah Cihampelas Kabupaten Bandung Barat menggunakan sistem seleksi. Seleksi penerimaan peserta didik baru menekankan pada seleksi administratif dan tes. Seleksi melalui tes ini dibagai menjadi dua yaitu dengan tes wawancara secara individu dan tes secara keseluruhan yang mencakup pengetahuan umum dan kemampuan akademik siswa.

Adapun proses penerimaan peserta didik baru di SMP Darul Falah Cihampelas Kabupaten Bandung Barat berlangsung dengan kurun waktu 4 bulan. Calon peseta didik yang mendaftar ke SMP Darul Falah Cihampelas Kabupaten Bandung Barat datang dari berbagai daerah, bahkan dari luar pulau Jawa. Beberapa tahun terakhir ini SMP Darul Falah Cihampelas Kabupaten Bandung Barat mengalami kenaikan tingkat pendaftaran calon peserta didik baru yang ingin masuk ke SMP Darul Falah Cihampelas Kabupaten Bandung Barat, yakni sekitar 1.000 peserta didik yang mendaftar dan hanya 407 peserta didik yang diterima.

Peserta didik yang diterima di SMP Darul Falah Cihampelas Kabupaten Bandung Barat harus mengikuti serangkaian tes seleksi yang ketat mulai dari pemeriksaan administrasi peserta didik yang dilanjutkan dengan tes baca tulis Al-Quran (BTQ), kemudian tes potensi akademik (TPA) dan ditutup dengan tes berupa wawancara. Hal ini dilakukan karena pihak sekolah menginginkan peserta didik yang diterima merupakan orang yang tepat dari segi kemampuan, minat dan bakatnya.

SMP Darul Falah Cihampelas Kabupaten Bandung Barat merupakan Sekolah Menengah Pertama berbasis pesantren, maka penentuan jumlah peserta didik dalam satu rombongan belajarnya tidak sesuai dengan jumlah maksimum rombongan belajar pada jenjang Sekolah Menengah Pertama yang ditetapkan oleh Permendikbud No. 22 Tahun 2016 yakni 32 peserta didik dalam satu rombongan belajar, sedangkan di SMP Darul Falah Cihampelas Kabupaten Bandung Barat memaksimalkan 36-40 peserta didik dalam satu rombongan belajarnya. 
Berdasarkan fenomena diatas, ada beberapa hal yang menarik untuk diteliti mengenai manajemen rekrutmen peserta didik dalam meningkatkan mutu lulusan di SMP Darul Falah Cihampelas Kabupaten Bandung Barat, sehingga dapat diidentifikasi permasalahannya menjadi, bagaimana kebijakan rekrutmen, sistem rekrutmen, kriteria penerimaan, prosedur penerimaan, serta hasil pelaksanaan rekrutmen peserta didik di SMP Darul Falah Cihampelas Kabupaten Bandung Barat.

\section{METODE PENELITIAN}

Penelitian ini menggunakan pendekatan kualitatif. Pendekatan kualitatif adalah mengungkapkan fakta yang ada kemudian dijelaskan secara deskriptif dengan kata-kata dan uraian. Penelitian ini menggambarkan secara objektif dan apa adanya mengenai manajemen rekrutmen peserta didik dalam meningkatkan mutu lulusan di SMP Darul Falah Cihampelas Kabupaten Bandung Barat. Tujuan penelitian kualitatif pada umumnya mencakup informasi tentang fenomena utama yang dieksplorasi dalam penelitian. Partisipan penelitian dan lokasi penelitian (Creswell, 2017, hlm. 164).

Adapun metode yang digunakan dalam penelitian ini adalah metode deskriptif. Metode deskriptif adalah metode yang digunakan untuk menggambarkan tentang realita manajemen rekrutmen peserta didik dalam meningkatkan mutu lulusan di SMP Darul Falah Cihampelas Kabupaten Bandung Barat.

Data primer didapatkan melalui wawancara terhadap Kepala Sekolah SMP Darul Falah yaitu Drs. H. Baehaqi, M.Si. sebagai key informan diikuti dengan snow ball process yaitu Kepala Tenaga Administrasi Sekolah H. Kusdina Toha Mumin, M.Pd.I, Wakil Kepala Bidang Kurikulum Yudi Supriadi, S.Pd, dan Ketua Panitia PPDB Rahmat Sodik, S.Pd secara bergulir dan baru dihentikan apabila terjadi pengulangan informasi. Selain itu, penelitian ini menggunakan data tambahan berupa dokumen, arsip, buku-buku referensi, dan sumber data lainnya yang dapat menunjang terhadap sumber data.

Teknik Penelitian yang digunakan dalam pengumpulan data yaitu observasi partisipasi, wawancara, dan studi dokumentasi. Analisis data dilakukan dengan kategorisasi data, penafsiran data. Adapun uji absah data dilakukan dengan perpanjangan keikutsertaan, ketekunan pengamatan, triangulasi, cek teman sejawat, analisis kasus negatif, kecukupan referensi dan uraian rinci.

\section{HASIL DAN PEMBAHASAN}

Pada awal berdirinya sekitar tahun 1970 Yayasan Pondok Pesantren Darul Falah merupakan sebuah pondok pesantren salafiyah yang tidak memiliki lembaga formal, kecuali sebuah rumah milik mertua sesepuh pondok yang difungsikan sebagai asrama santri sekaligus madrasah. Didirikan oleh seorang kyai muda yaitu KH. Asep Burhanudin. Seiring perkembangan zaman, pada tahun 1985 beliau meningkatkan aktivitas pendidikan dan dakwahnya dengan mendidirikan Yayasan Pondok Pesantren Darul Falah yang berakta notaris No. 22 tahun 1985, yang kemudian mendirikan pendidikan formal yaitu SMP Darul Falah, yang merupakan sekolah pertama didirikan di Cihampelas - Cililin yang bernuansa Nahdatul Ulama (NU). 
Sekolah ini awalnya memanfaatkan madrasah tua yang berukuran $10 \times 5$ meter yang dijadikan dua ruang kelas, masing-masing berukuran 4x5 meter dan 1 kamar berukuran 2x2,5 meter untuk kantor dan satu MCK berukuran 2×2,5 meter, sedangkan siswa yang daftar sebanyak 62 orang. Dipimpin oleh seorang tokoh berpengalaman dalam bidang Almaarif (NU) di Wilayah Cililin yaitu Bapak Wajun (Alm) pada saat itu beliau sebagai Ketua MWC NU Cililin, dibantu oleh aktivis pesantren dan NU (GP Anshor/PMII) yang rata-rata masih berstatus mahasiswa/santri seperti $\mathrm{CH}$. Anwar Hidayat, Agus Gunawan,BA, A. Saeful Mu'min,BA, Baehaqi,BA, Agus HD.Idris, lis Holiah, dan lain-lain. Pada Tahun 1987 didirikan Madrasah Aliyah, dipimpin Drs.A.Saeful Mu'min, H.Asep Suryana. Kemudian pada tahun 1992 berubah menjadi SMA Darul Falah dipimpin Drs.Effendi (Alm) dan sempat dipimpin oleh H. Kodar Rohmat pada tahun 20062007 dan kini dipimpin oleh H. A. Ghozwan Solihin, M.Pd.

Dari tahun berdirinya SMP Darul Falah hingga saat ini sudah terjadi beberapa pergantian kepala sekolah, diantaranya yaitu: 1) Wajun (1985-1986), 2) Drs. Dendih Erawan (semester 1, tahun ajaran 1986-1987), dan 3) Drs. H. Baehaqi., M.Si. (1987-sekarang). Pada Era kepemimpinan Bapak Drs. H. Baehaqi, M.Si, terjadi kemajuan yang signifikan dalam berbagai capaian prestasi, baik akademik maupun non akademik. Sehingga pada tahun-tahun itu animo masyarakat begitu antusias untuk memasukan putra-putrinya di SMP Darul Falah Cihampelas Kabupaten Bandung Barat. Tercatat dalam data jumlah siswa alumni siswa SMP Darul Falah Cihampelas Kabupaten Bandung Barat berjumlah ribuan sampai dengan tahun 2018 masing-masing paralel 3 sehingga jumlah kelas yang ada sebanyak 33 kelas, dan setiap kelasnya rata-rata 40 siswa.

\section{Kebijakan Penerimaan Peserta Didik Baru}

SMP Darul Falah Cihampelas Kabupaten Bandung Barat pada tahap pembuatan kebijakan rekrutmen peserta didik baru disesuaikan dengan petunjuk-petunjuk Dinas Pendidikan Kabupaten/ Kota dan juga disesuaikan dengan Data Pokok Pendidikan Nasional (Dapodik) dan target sekolah yang ingin dicapai. Kebijakan ini memuat aturan mengenai jumlah peserta didik yang diterima di suatu sekolah. Penentuan mengenai jumlah peserta didik, tentu juga didasarkan atas kenyataan-kenyataan yang ada di sekolah (faktor kondisional sekolah). Faktor kondisional tersebut meliputi daya tampung kelas baru, kriteria mengenai siswa yang dapat diterima, anggaran yang tersedia, prasarana dan sarana yang ada, tenaga kependidikan yang tersedia, jumlah peserta didik yang tinggal di kelas satu, dan sebagainya.

Daya tampung penerimaan peserta didik baru tahun pelajaran 2018/2019 di SMP Darul Falah Cihampelas Kabupaten Bandung Barat adalah sebanyak 5 kelas untuk Program Kelas Unggulan (PKU) dan 6 kelas untuk Program Kelas Reguler (PKR). Dengan jumlah masing-masing peserta didik disetiap kelas kurang lebih terdiri dari 32 peserta didik untuk PKU, dan 36 peserta didik untuk PKR, sehingga jumlah siswa kelas VII keseluruhannya sebanyak 394 peserta didik.

Kemudian untuk kebijakan operasional penerimaan peserta didik baru di SMP Darul Falah Cihampelas Kabupaten Bandung Barat memuat tentang sistem pendaftaran dan seleksi atau penyaringan peserta didik yang akan diberlakukan di SMP Darul Falah Cihampelas Kabupaten Bandung Barat. Selain itu, kebijakan 
penerimaan peserta didik di SMP Darul Falah Cihampelas Kabupaten Bandung Barat juga berisi mengenai waktu pendaftaran, kapan dimulai dan kapan diakhiri. Selanjutnya, kebijakan penerimaan peserta didik harus juga memuat tentang personalia-personalia yang akan terlibat dalam pendaftaran, seleksi dan penerimaan peserta didik.

\section{Sistem Penerimaan Peserta Didik}

Sistem yang dimaksudkan disini lebih menunjuk kepada cara penerimaan peserta didik baru di SMP Darul Falah Cihampelas Kabupaten Bandung Barat. Adapun cara atau alur penerimaan peserta didik baru di SMP Darul Falah Cihampelas Kabupaten Bandung Barat adalah dengan melakukan pendaftaran, melengkapi data offline/online, tes baca tulis AI-Quran dan latin, wawancara, tes potensi akademik, pengumuman kelulusan, mengikuti MPLSB/Taaruf dan dinyatakan resmi menjadi siswa baru SMP Darul Falah Kabupaten Bandung Barat.

Cara penerimaan peserta didik baru yang dilaksanakan di SMP Darul Falah Cihampelas Kabupaten Bandung Barat menggunakan sitem seleksi secara tes, bahwa calon peserta didik baru yang mendaftar diwajibkan menyelesaikan tugas berupa soal-soal tes secara lisan maupun tertulis. Jika peserta didik dapat menyelesaikan suatu tugas berdasarkan kriteria tertentu yang telah ditentukan, maka peserta didik tersebut akan diterima. Sebaliknya jika mereka tidak dapat menyelesaikan tugas berdasarkan kriteria yang ditentukan sekolah, maka yang bersangkutan tidak dapat diterima sebagai peserta didik di SMP Darul Falah Cihampelas Kabupaten Bandung Barat. Sistem seleksi ini dilakukan melalui dua tahap, yakni seleksi administratif dan kemudian seleksi akademik. Seleksi administratif ini berupa kelengkapan-kelengkapan administratif peserta didik, apakah kelengkapan-kelengkapan administratif yang di persyaratkan telah terpenuhi atau tidak.

\section{Kriteria Penerimaan Peserta Didik Baru}

SMP Darul Falah Cihampelas Kabupaten Bandung Barat dalam menentukan kriteria penerimaan peserta didik baru menggunakan teori kriteria acuan patokan, kriteria acuan norma dan kriteria yang didasarkan atas daya tampung sekolah dimana pihak sekolah terlebih dahulu menentukan berapa jumlah daya tampung kelas sesuai dengan anjuran Data Pokok Pendidikan Nasional (Dapodik), kemudian membuat kriteria/persyaratan yang harus dipenuhi oleh calon peserta didik baru, salah satunya peserta didik yang mendaftar ke SMP Darul Falah Ciampelas Kabupaten Bandung Barat harus mengikuti serangkaian tes seleksi yang sudah di persiapkan pihak sekolah, dan setelah itu keseluruhan prestasi peserta didik yang mengikuti serangkaian tes seleksi dijumlah, dan dicari rata-ratanya. Calon peserta didik yang nilainya berada di atas rata-rata, digolongkan sebagai calon yang dapat diterima sebagai calon peserta didik. Sementara yang berada di bawah rata-rata termasuk peserta didik yang tidak diterima.

\section{Prosedur Penerimaan Peserta Didik Baru}

Penerimaan peserta didik baru di SMP Darul Falah Cihampelas Kabupaten Bandung Barat dilakukan melalui beberapa tahapan atau prosedur yang telah 
ditetapkan oleh pihak Sekolah, yaitu membentuk panitia PPDB, rapat panitia PPDB, pendaftaran, proses penerimaan peserta didik baru, tes seleksi, pengumuman kelulusan, pendaftaran ulang, mengikuti MPLSB/Taaruf dan dinyatakan resmi menjadi siswa baru SMP Darul Falah.

\section{Pembentukan Panitia Penerimaan Peserta Didik Baru}

Pembentukan panitia penyelenggara penerimaan peserta didik baru adalah seluruh proses pengelompokkan orang-orang, alat-alat, tanggung jawab, dan wewenang sedemikian rupa untuk mencapai suatu tujuan tertentu. Dalam pembentukan panitia Penerimaan Peserta Didik Baru (PPDB) SMP Darul Falah Cihampelas Kabupaten Bandung Barat tahun pelajaran 2018/2019, telah melakukan pembagian tugas pada berbagai bidang. Hal ini bertujuan agar para panitia dapat memfokuskan dirinya pada bidangnya masing-masing. Karena dalam hal ini, panitia berperan sebagai roda organisasi dan pelaksana seluruh mekanisme kerja yang telah tersistemisasi secara akurat pada program kerja.

Seiring dengan adanya program kerja dan rangkaian tugas dan kewajiban yang harus diselesaikan selama kegiatan berlangsung. Maka penyelenggaraan penerimaan peserta didik baru (PPDB) SMP Darul Falah Cihampelas Kabupaten Bandung Barat tahun pelajaran 2018/2019 telah dibentuk susunan kepanitiaan dengan komposisi diantaranya 1 orang penanggung jawab, 3 orang steering commite, 1 orang ketua pelaksana, 2 orang sekretaris, 2 orang bendahara, 7 orang koordinator bidang, dan 22 orang anggota yang terdiri dari bidang publikasi, bidang akomodasi, bidang konsumsi, bidang MPLS (Masa Pengenalan Lingkungan Sekolah), bidang pendaftaran, dan bidang tes baca tulis AI-Quran.

\section{Rapat Penentuan Peserta Didik Baru}

Rapat penerimaan peserta didik baru dipimpin oleh ketua PPDB secara langsung. Rapat tersebut diadakan sebulan sebelum pelaksanaan penerimaan peserta didik baru dimulai. Dalam rapat ini keseluruhan anggota panitia dapat berbicara sesuai dengan kapasitas mereka masing-masing. Jadi dalam rapat ini seluruh anggota panitia bisa menyalurkan aspirasinya. Aktivitas-aktivitas yang dilakukan dibicarakan setuntas mungkin sehingga setelah rapat selesai, seluruh anggota panitia tinggal menindaklanjuti saja, seperti apa yang sudah diputuskan dalam rapat tersebut, yang memperoleh tugasnya harus menindak lanjuti. Dan hasil rapat panitia penerimaan peserta didik baru tersebut dicatat dalam buku notulen rapat. Catatan tentang rapat sangat penting karena dapat dijadikan sebagai salah satu bahan untuk membuat keputusan-keputusan sekolah. Dalam rapat tersebut banyak sekali pikiran-pikitran dan gagasan-gagasan cemerlang yang perlu didokumentasikan.

\section{Pembuatan pengiriman/ pemasangan pengumuman}

Pembuatan dan pemasangan pengumuman penerimaan peserta didik baru di SMP Darul Falah Cihampelas Kabupaten Bandung Barat dilakukan secara terbuka. Dengan menggunakan papan pengumuman sekolah yang berisi tentang tempat pendaftaran, waktu dan tempat seleksi yang meliputi hari, tanggal, jam dan tempat seleksi, dan pengumuman hasil seleksi tes.

Pada dasarnya tidak ada penolakan dalam hal penerimaan peserta didik baru pada SMP Darul Falah Cihampelas Kabupaten Bandung Barat kecuali jika 
fasilitas tidak memadai, calon peserta didik baru bisa memenuhi persyaratan yang telah ditentukan sesuai dengan ketentuan Departemen Pendidikan Nasional disamping ketentuan dari SMP Darul Falah Cihampelas Kabupaten Bandung Barat, dan kedudukan sosial dan jabatan orang tua/wali peserta didik baru tidak menjadi pertimbangan dalam Penerimaan Peserta Didik Baru (PPDB).

\section{Pendaftaran Peserta Didik Baru}

Untuk pendaftaran calon peserta didik baru mereka langsung datang ke loket pendaftaran yang sudah disediakan di SMP Darul Falah Cihampelas Kabupaten Bandung Barat. Pendaftarannya dilakukan secara tertulis menggunakan format khusus yang sudah disediakan, selain itu juga calon peserta didik yang mendaftar diharuskan mengisi format pendaftaran secara online melalui website SMP Darul Falah Cihampelas Kabupaten Bandung Barat. Untuk mendapatkan formulir pendaftaran, sebelumnya calon peserta didik di SMP Darul Falah Cihampelas Kabupaten Bandung Barat dipersilahkan untuk daftar ke panitia rekrutmen penerimaan peserta didik baru untuk mengisi identitas seperti nama calon peserta didik, alamat dan asal sekolah. Setelah itu panitia memberikan nomor dan formulir pendaftaran, menyuruh untuk mengisi formulirnya, syarat-syaratnya dilengkapi, membayar biaya pendaftaran dan kemudia dikembalikan pada waktu yang telah ditentukan oleh pihak SMP Darul Falah Cihampelas Kabupaten Bandung Barat.

Loket pendaftaran peserta didik baru berada di ruang Tata Usaha yang telah disiapkan panitia pengurus pendaftaran yaitu Bapak Rijal Ramdani. Loket pendaftaran penerimaan peserta didik baru selalu di buka setiap hari kerja yaitu pagi mulai pukul 08.00-12.00 WIB dan siang mulai pukul 13.00-16.00 WIB. Loket ini digunakan untuk pendafran penerimaan peserta didik baru dan untuk pengisian formulir pendaftaran.

Formulir pendaftaran dimaksudkan untuk mengetahui identitas calon peserta didik baru dan untuk kepentingan pengisian buku induk sekolah. Formulir pendaftaran di SMP Darul Falah Cihampelas Kabupaten Bandung Barat diberikan kepada wali murid pada saat mendaftarkan putra-putrinya. Kemudian pengisian formulir dilakukan di tempat yang telah disediakan dan dibantu oleh salah satu panitia yang bertugas.

\section{Seleksi Peserta Didik Baru}

Ketentuan untuk diterima menjadi peserta didik di SMP Darul Falah Cihampelas Kabupaten Bandung Barat menggunakan seleksi tes. Sehingga, untuk masuk ke SMP Darul Falah Cihampelas Kabupaten Bandung Barat harus melalui proses dan tidak semua yang mendaftar ke lembaga tersebut bisa diterima. Seleksi yang digunakan oleh SMP Darul Falah Cihampelas Kabupaten Bandung Barat yaitu seleksi secara offline. Dengan diberikan tiga jenis tes, diantaranya adalah tes tertulis yang didalamnya terdapat soal mata pelajaran umum (IPA, Bahasa Indonesia, dan Bahasa Inggris) dan soal mata pelajaran keagamaan, selanjutnya tes lisan (wawancara) bersama calon peserta didik, tes Baca Tulis Quran (BTQ) dan tes baca tulis latin.

SMP Darul Falah Cihampelas Kabupaten Bandung Barat melalui ketua panitia penerimaan peserta didik baru menyatakan bahwa gabungan dari ketiga tes yang diberikan kepada calon peserta didik baru diharapkan dapat mengukur 
kemampuan dan kulaitas peserta didik baru sesuai dengan yang diinginkan oleh lembaga sehingga lembaga juga dipermudah untuk mengantarkan peserta didik yang telah diterima dari hasil seleksi tersebut, menjadi peserta didik yang berprestasi sesuai dengan minat dan bakatnya.

\section{Penentuan Peserta Didik Yang Diterima}

Penentuan peserta didik baru yang diterima di SMP Darul Falah Cihampelas Kabupaten Bandung Barat disesuaikan dengan daya tampung sekolah dan berdasarkan hasil tes seleksi yang telah diikuti oleh calon peserta didik baru, kemudian pihak sekolah mengumumkan secara resmi dan sah secara yuridis oleh panitia penerimaan peserta didik baru. Dan untuk transparansi data pihak panitia penerimaan peserta didik baru menempelkan hasil tes seleksi peserta didik secara keseluruhan baik itu seleksi secara lisan dan tulisan di papan pengumuman sekolah, sehingga peserta didik yang mendaftar serta orangtua wali dapat melihat hasil dan kemampuan anaknya pada saat melaksanakan tes, dan juga dapat melihat apakah peserta didik tersebut dinyatakan lulus atau tidak. Transparansi data ini dilakukan agar peserta didik dan orangtua wali dapat memahami ketika peserta didik tersebut tidak dapat diterima di SMP Darul Falah Cihampelas Kabupaten Bandung Barat karena telah melihat secara langsung hasil dari setiap seleksi tes yang dilakukan.

\section{Pendaftaran Ulang}

Setelah diadakan pendaftaran calon peserta didik baru, kemudian dilakukan tes seleksi, pengumuman peserta didik yang diterima atau tidak dan selanjutnya adalah pendaftaran ulang (registrasi). Pendaftaran ulang dilakukan setelah peserta didik dinyatakan lulus pada seleksi tes yang diselenggarakan oleh pihak sekolah. Setelah peserta didik yang bersangkutan dinyatakan lulus atau diterima, maka peserta didik diharuskan untuk memenuhi persyaratan dan kelengkapan data yang diminta sekolah guna untuk melakukan daftar ulang, adapun batasan waktu pendaftaran ulang yaitu pada tanggal 2 juni 2018 sampai 9 juni 2018.

\section{Capaian Hasil Manajemen Rekrutmen Peserta Didik Dalam Meningkatkan Mutu Lulusan}

Hasil yang di dapat dari rekrutmen peserta didik dalam meningkatkan mutu lulusan di SMP Darul Falah Cihampelas Kabupaten Bandung Barat dari 3 tahun terakhir hingga saat ini di tahun ajaran 2018-2019 selalu mencapai target dan bahkan terus mengalami peningkatan. SMP Darul Falah Cihampelas Kabupaten Bandung Barat termasuk sebuah sekolah menengah pertama yang mampu menampakkan eksistensinya di dunia pendidikan umum maupun pendidikan Islam, dan menjadi sekolah yang diminati pada aspek pembelajarannya. Adapun implikasi manajemen rekrutmen peserta didik dalam meningkatkan mutu lulusan di SMP Darul Falah Cihampelas Kabupaten Bandung Barat, yaitu mempermudah pihak sekolah dalam mengembangkan minat, bakat dan potensi peserta didik, mendapatkan input yang berkualitas sesuai dengan visi, misi dan tujuan sekolah, meningkatkan pelayanan pendidikan dan mendapatkan output yang baik dari prestasi sekolahnya, prestasi peserta didiknya, maupun prestasi dari para alumninya. 
Mendapatkan peserta didik yang berkualitas melalui seleksi tes masuk, setidaknya lembaga akan lebih mudah menjalankan kegiatan pada tahap selanjutnya, yaitu dalam proses pembelajaran. Karena pemahaman dan pengalaman yang diperoleh sebelumnya merupakan kemampuan awal peserta didik yang dapat mempermudah memperoleh pengetahuan baru. Pelaksanaan PPDB tidak hanya semata-mata untuk memenuhi kebutuhan peserta didik saja, akan tetapi merupakan bagian kegiatan dalam menciptakan lembaga pendidikan agar tetap bermutu.

Dalam konteks pendidikan indikator mutu lulusan berpedoman pada hasil pendidikan yang mengacu pada prestasi yang dicapai oleh sekolah pada setiap kurun waktu tertentu (misalnya: setiap catur wulan, semester, setahun, 5 tahun dan sebagainya). Prestasi yang dicapai dapat berupa hasil tes kemampuan akademik, seperti ulangan umum, ujian nasional, atau prestasi bidang lain, misalnya prestasi di bidang seni. Bahkan prestasi sekolah berupa kondisi yang tidak dapat dipegang, seperti suasana disiplin, keakraban, saling menghormati, dan sebagainya.

Dengan mendapatkan prestasi peserta didik yang berkualitas dapat berpeluang dalam menunjang peningkatan mutu sekolah secara umum dan mutu lulusan secara khusus. Karena langkah pertama yang mencerminkan berhasil tidaknya suatu lembaga pendidikan dalam mencapai tujuannya adalah jika peserta didik yang diterima mempunyai kompetensi sesuai syarat, maka usaha untuk mewujudkan tujuan lembaga pendidikan tersebut akan relatif mudah, demikian pula sebaliknya.

\section{SIMPULAN}

Kebijakan rekrutmen peserta didik baru di SMP Darul Falah Cihampelas Kabupaten Bandung Barat pada tahap pertama itu penetapan daya tampung peserta didik untuk melihat kapasitas jumlah ruang kelas yang tersedia agar kedepannya mempermudah dalam pelaksanaannya. Kemudian memuat tentang sistem pendaftaran dan seleksi atau penyaringan peserta didik baru untuk dapat diterima di sekolah yang bersangkutan. Selain itu memuat tentang personaliapersonalia yang akan terlibat dalam pendaftaran, seleksi, dan penerimaan peserta didik baru. Serta yang terakhir persiapan administrasi serta sarana dan prasarana yang diperlukan. Sistem penerimaan peserta didik baru yang dimaksudkan disini lebih menunjuk kepada cara penerimaan peserta didik baru di SMP Darul Falah Cihampelas Kabupaten Bandung Barat. Adapun cara atau alur penerimaan peserta didik baru di SMP Darul Falah Cihampelas Kabupaten Bandung Barat adalah dengan melakukan pendaftaran, melengkapi data offline/online, tes baca tulis Al-Quran dan latin, wawancara, tes potensi akademik, pengumuman kelulusan, mengikuti MPLSB/Taaruf dan dinyatakan resmi menjadi siswa baru SMP Darul Falah. Kriteria penerimaan peserta didik baru merupakan patokan-patokan yang menentukan bisa atau tidaknya seseorang untuk diterima sebagai peserta didik. Ada tiga macam kriteria yang dijadikan patokan dalam penerimaan peserta didik baru di SMP Darul Falah Cihampelas Kabupaten Bandung Barat, yaitu pertama, adalah kriteria acuan patokan (standard criterian referenced). Kedua, kriteria acuan norma (norm ceriterian referenced). Ketiga, yang didasarkan atas daya tampung sekolah. Prosedur penerimaan peserta didik baru di SMP Darul Falah Cihampelas 
Kabupaten Bandung Barat meliputi pembentukan panitia penerimaan peserta didik baru, rapat penerimaan peserta didik baru, pembuatan pengumuman peserta didik baru, pemasangan/pengiriman pengumuman peserta didik baru, pendaftaran peserta didik baru, seleksi peserta didik baru, rapat penentuan peserta didik yang diterima, pengumuman peserta didik yang diterima, dan pendaftaran ulang peserta didik baru. Hasil dari manajemen rekrutmen peserta didik dalam meningkatkan mutu Iulusan di SMP Darul Falah Cihampelas Kabupaten Bandung Barat yaitu mempermudah pihak sekolah dalam menentukan minat, bakat dan potensi peserta didik serta mendapatkan input yang berkualitas.

\section{REFERENSI}

Ardhi, M. I. (2015). Evaluasi Manajemen Penerimaan Peserta Didik Baru Sistem Real Time Online Dinas Pendidikan Kota Yogyakarta. JURNAL PENELITIAN ILMU PENDIDIKAN, 8(1). https://doi.org/10.21831/jpipfip.v8i1.4930

Badrudin, B. (2013). Manajemen Peserta Didik. PT Indeks.

Creswell, J. W. (2017). Research Design (Pendekatan Metode Kualitatif, Kuantutatif, dan Campuran). Pustaka Pelajar.

Deniyati, N. (2017). Manajemen Rekrutmen Peserta Didik. Jurnal Isema: Islamic Educational Management, 2(2), 33-39. https://doi.org/10.15575/isema.v2i2.5000

Heryati, Y., \& Muhsin, M. (2014). Manajemen Sumber Daya Pendidikan. Pustaka Setia.

Imron, A. (2012). Manajemen Peserta Didik Berbasis Sekolah. Bumi Aksara. Jahari, J., Khoiruddin, H., \& Nurjanah, H. (2019). Manajemen Peserta Didik. Jurnal Isema : Islamic Educational Management, 3(2), 53-63. https://doi.org/10.15575/isema.v3i2.5009

Junaidi, J. (2016). Pelaksanaan Manajemen Peserta Didik Pada MAN Beringin Kota Sawahlunto. al-fikrah: Jurnal Manajemen Pendidikan, 3(1), 37. https://doi.org/10.31958/jaf.v3i1.388

Nizarman, N. (2015). Manajemen Penerimaan Siswa Baru. MAPEN: Jurnal Manajer Pendidikan, 9(2), 224-234.

Prihatin, E. (2011). Manajemen Peserta Didik. PT Alfabeta.

Tien, Y. C. (2015). Manajemen Peningkatan Mutu Lulusan. MAPEN: Jurnal Manajer Pendidikan, 9(4), 579-587.

Tim Dosen Adpen UPI. (2015). Manajemen Pendidikan. Alfabeta.

Ubaidillah, A. (2017). Rekrutmen Peserta Didik Dalam Meningkatkan Mutu Lembaga Pendidikan (Studi Multisitus di MAN 1 Malang dan SMA Negeri 3 Malang) [Thesis]. Universitas Islam Negeri Maulana Malik Ibrahim.

Umam, M. K. (2018). Peningkatan Mutu Pendidikan Melalui Manajemen Peserta Didik. Jurnal al-Hikmah, 6(2), 62-76. 